\title{
PENGARUH PENGGUNAAN MODEL KOOPERATIF TIPE STAD TERHADAP KETERAMPILAN MENULIS TEKS DESKRIPSI SISWA KELAS VII SMP NEGERI 12 TANJUNG JABUNG TIMUR
}

\author{
Andi Santoso', Abdoel Gafar' ${ }^{2}$, Firman Tara ${ }^{3}$ \\ Program Studi Pendidikan Bahasa dan Sastra Indonesia, \\ Fakultas Keguruan dan Ilmu Pendidikan, Universitas Batanghari, \\ Jambi \\ andikzhenk@gmail.com \\ gafar3r@yahoo.co.id \\ firmantara14@gmail.com
}

\begin{abstract}
This purposes of this research are (1) to identify the effect of the cooperative model STAD type on students' writing skill of seventh grade students of SMP Negeri 12 Tanjung Jabung Timur academic year 2019/2020, and (2) to describe the steps of writing descriptive text through the cooperative model STAD type of class VII students of SMP Negeri 12 Tanjung Jabung Timur academic year 2019/2020. This research is Quasi-Experimental. The subjects of the research was the students of class VII SMP Negeri 12 Tanjung Jabung Timur in which 30 students in control class and 30 students in experimental class. The data was taken by written test techniques. The data analysis was done by calculating the total score of the control class and the experimental class of each student which was then compared with their skill categories. The indicator of success in this research is the effect of students' ability in writing descriptive text in class VII of SMP Negeri 12 Tanjung Jabung Timur through the use of cooperative learning model STAD type. This research is said to be successful if the percentage of the students in the experimental class is 82.63 higher than the control class which falls into 70.20. The results showed: (1) the use of cooperative learning model type STAD has an effect in writing descriptive text. (2) The steps of the cooperative learning model STAD type in writing descriptive text are: 1) conveying goals and motivating students, 2) presenting information, 3) organizing students in cooperative groups, 4) guiding groups to work and study, 5) evaluating, and 6) giving awards. Thus the cooperative learning model STAD type significantly influence students' skill in writing descriptive text.
\end{abstract}

Keywords: cooperative STAD type, writing ability, descriptive text

\footnotetext{
${ }^{1}$ Mahasiswa Program Studi Pendidikan Bahasa dan Sastra Indonesia, Fakultas Keguruan dan Ilmu Pendidikan, Universitas Batanghari, Jambi

${ }^{2}$ Dosen Program Studi Pendidikan Bahasa dan Sastra Indonesia, Fakultas Keguruan dan Ilmu Pendidikan, Universitas Batanghari, Jambi

${ }^{3}$ Dosen Program Studi Pendidikan Bahasa dan Sastra Indonesia, Fakultas Keguruan dan Ilmu Pendidikan, Universitas Batanghari, Jambi
} 


\section{PENDAHULUAN}

Pendidikan merupakan suatu hal yang sangat mutlak dibutuhkan pada saat ini dan masa yang akan datang. Hal ini dikarenakan dari dunia pendidikan dapat menciptakan (SDM) sumber daya manusia akan bermutu. Maka dari itu pemerintah wajib mempersiapkan pelaksanaan sarana prasarana yang baik dan penyempurnaan kurikulum yang baik pula. Dengan adanya kurikulum yang baik maka guru diminta lebih kreatif dalam menyampaikan materi atau pembelajaran demi mencapai nilai kelulusan sesuai yang diharapkan. SMP N 12 Tanjung Jabung Timur merupakan salah satu sekolah model dan sekolah favorit yang terakreditasi A di Kabupaten Tanjung Jabung Timur yang telah mempunyai sarana dan prasarana yang lengkap untuk proses pembelajaran.

Dalam dunia pendidikan salah satu yang diajarkan adalah mata pelajaran bahasa Indonesia. Ruang lingkup mata pelajaran bahasa Indonesia di sekolah memuat empat aspek keterampilan berbahasa, yang diharapkan siswa menguasai keterampilan menyimak, berbicara, membaca dan menulis. Alasan tersebut sesuai dengan pendapat Tarigan (2013:1) "Keempat keterampilan tersebut pada dasarnya merupakan suatu kesatuan yang berkaitan". Dari keempat aspek tersebut menulis merupakan keterampilan yang penting untuk dipelajari di sekolah. Rofii dkk. (2019A) mengatakan "Writing skill is one of four language skills that must be mastered by students" (keterampilan menulis merupakan salah satu dari empat keterampilan berbahasa yang harus dikuasai oleh siswa.

Menulis merupakan keterampilan menuangkan ide sebagai hasil pemikiran ke dalam bentuk tulisan. Menulis bisa dikatakan sebagai proses menyampaikan pesan atau komunikasi kepada orang lain. Rofii dkk. (2019 C) mengatakan Writing is a complex activity requiring extensive and comprehensive knowledge (Menulis adalah kegiatan kompleks yang membutuhkan pengetahuan yang luas dan mendalam). "Fungsi utama dari menulis adalah sebagai alat komunikasi yang tidak langsung" (Tarigan, 2013:22). Menulis merupakan salah satu bakat atau kemampuan yang dimiliki oleh seseorang sejak lahir namun kemampuan tersebut membutuhkan proses dan latihan. "Kemampuan tersebut akan berkembang dengan baik apabila mendapatkan rangsangan dan pemupukan secara tepat" (Sunanto, 2008:5). Selama proses pembelajaran ada banyak jenis tulisan yang harus ditulis oleh peserta didik salah satu materi menulis di kelas VII adalah menulis teks deskripsi. Hal ini juga merupakan tuntutan kurikulum K13. Begitu juga halnya dengan SMP Negeri 12 Tanjung Jabung Timur menerapkan kurikulum 2013 salah satu yang dipelajari adalah keterampilan menulis teks Deskripsi yang terdapat pada (KI) 3 mencoba, mengelolah, dan menyajikan dalam ranah konkret dan ranah abstrak, pada kompetensi dasar (KD) 4.2 Menyajikan data, gagasan, kesan dalam bentuk teks deskripsi tentang objek (sekolah, tempat wisata, tempat bersejarah, dan atau suasana pentas seni daerah) secara tulis dan lisan dengan memperhatikan struktur, kebahasaan baik secara lisan maupun tulis.

Setiap tulisan dengan mempergunakan corak deskripsi, harus mempunyai tujuan tertentu. "Dalam menulis teks deskripsi semua daya upaya dapat dipergunakan semaksimal mungkin untuk mencapai tujuan karangan itu, atau secara efektif menyampaikan amanat yang terkandung dalam karangan itu" (Keraf, 2018:104). Upaya yang pertama-tama dapat digunakan adalah cara menyusun detail-detail dari objek itu. Disamping cara penyusunan isi, penulis harus memperhatikan pula sebuah segi lain yaitu 
pendekatan (approach), yaitu bagaiman caranya siswa meneropong atau melihat objek yang akan dituliskan itu. Sikap mana yang harus diambilnya agar siswa dapat menggambarkan objeknya itu secara tepat sehingga maksudnya itu dapat tercapai.

Dari hasil observasi dan wawancara penulis dengan guru mata pelajaran Bahasa Indonesia kelas VII, pada tanggal 14 November 2019 kendala yang ditemui oleh guru dalam pembelajaran teks deskripsi sebagai berikut. Guru itu belum menggunakan model kooperatif tipe STAD (student teams achivement divisions) dalam pembelajaran ini, maka di dalam pemahaman penulis. Penulis berkeinginan menerapkan model kooperatif tipe STAD dalam pembelajaran ini.

Untuk mengatasi masalah di atas, maka perlu disiasati dengan melakukan penggunaan model dalam pembelajaran. Hal ini sesuai dengan pendapat Rofii, Murtadho, dan Rahmat (2019C) yang mengatakan bahwa salah satu upaya yang dapat digunakan untuk mewujudkan pembelajaran efektif dalam mengoptimalkan hasil belajar, yakni dengan cara menggunakan model pembelajaran. Salah satu model pembelajaran yang tepat digunakan untuk kemampuan menulis teks deskripsi adalah model kooperatif. Dengan diterapkannya model pembelajaran kooperatif diharapkan mampu mengajarkan siswa untuk mengutamakan kerjasama antara kelompok meningkatkan prestasi belajar siswa dan membuat siswa dapat bekerjasama dengan aktif, kritis, dan positif.

Model pembelajaran kooperatif tipe STAD merupakan salah satu tipe pembelajaran kooperatif yang paling sederhana. Model pembelajaran kooperatif ini dirasa lebih mampu untuk memotivasi siswa agar lebih semangat lagi dalam belajar dan dapat menumbuhkan ide kreatif dari siswa. Model pembelajaran tipe STAD memberikan penghargaan atau reward kepada siswa. Pemberian reward akan mendorong dan memotivasi siswa untuk lebih giat belajar serta akan memberikan suasana persaingan sehat diantara siswa. Dengan model pembelajaran kooperatif tipe STAD diharapkan mampu meningkatkan kemampuan menulis teks deskripsi siswa, karena siswa dapat bertukar pikiran dengan teman satu kelompok dan bersaing secara sehat untuk memperoleh reward atau penghargaan dari guru.

Tujuan penelitian ini adalah, pertama, mendeskripsikan kemampuan menulis teks deskripsi siswa kelas VII $\begin{array}{llll}\text { SMP } & \mathrm{N} & 12 & \text { Tanjung }\end{array}$ Jabung,Timur,sebelum,menggunakan,mod el,pembelajaran,kooperatif,,tipe,STAD..Ke dua,,mendeskripsikan kemampuan menulis teks deskripsi siswa kelas VII SMP N 12 Tanjung Jabung Timur sesudah menggunakan model pembelajaran kooperatif tipe STAD. Ketiga, mendeskripsikan pengaruh model pembelajaran kooperatif tipe STAD terhadap kemampuan menulis teks deskripsi siswa kelas VII SMP N 12 Tanjung Jabung Timur.

Menurut Darmawati (2014:2) mengatakan bahwa teks deskripsi berisi penggambaran secara jelas dan terperinci suatu objek, tempat, atau peristiwa tertentu kepada pembaca. Priyatni (2014:72) mengungkapkan bahwa teks deskripsi merupakan teks yang memaparkan suatu objek/hal/keadaan secara rinci sehingga pembaca seolah-olah mendengar, melihat, atau merasakan hal yang dipaparkan. Teks deskripsi bertujuan menjelaskan pengalaman yang berhubungan dengan 
hasil pengamatan pancaindera, seperti bentuknya, suaranya, rasanya, kelakuanya, atau gerak-geriknya.

Indikator teks deskripsi yang akan dijelaskan yaitu sebagai berikut. Pertama, judul pada teks deskripsi biasanya singkat, padat dan langsung merujuk kepada objek yang hendak dideskripsikan. Kedua, kalimat topik. Pada teks deskripsi diawali dengan kalimat topik yang berupa pernyataan-pernyataan umum. Ketiga, deskripsi. Deskripsi adalah rincian lebih lanjut dari kalimat topik yang mengambarkan hal/objek/keadaan secara spesifik dan rinci.

Rusman

menjelaskan bahwa model pembelajaran kooperatif tipe STAD dikembangkan oleh dikembangkan oleh Robert dan temantemanya di Universitas Jhon Hopking. Model kooperatif tipe merupakan model pembelajaran yang memacu siswa agar saling mendorong dan membantu satu sama lain untuk menguasai keterampilan yang diajarkan oleh guru, semua siswa bertukar pikiran dan saling membantu anggota kelompok masing-masing untuk mendapatkan nilai terbaik dan memperoleh penghargaan dari guru.

Berdasarkan uraian latar belakang di atas maka, penelitian tentang pengaruh penggunaan model kooperatif tipe STAD terhadap keterampilan menulis teks Siswa Kelas VII semester ganjil SMP Negeri 12 Tanjung Jabung Timur Tahun Pelajaran 2019/2020, ini penting untuk dilakukan.

\section{METODE PENELITIAN}

Menurut Narbuko

(2009:1)

"Penelitian adalah suatu kegiatan untuk mencari, mencatat, merumuskan dan menganalisis sampai menyusun laporanya". Selanjutnya menurut Sukmadinata (2010:287) "Desain penelitian merupakan rancangan bagaimana penelitian tersebut dilaksanakan". Berdasarkan pendapat tersebut maka dapat dikatakan bahwa desain penelitian merupakan semua proses penelitian yang dilakukan oleh penulis dalam melaksanakan penelitian, mulai dari perencanaan sampai pelaksanaan penelitian yang dilakukan pada waktu yang telah ditetapkan. "Desain penelitian kuantitatif dilakukan dengan menggunakan angka-angka, pengolahan statistik, struktur dan percobaan terkontrol" (Sukmadinata, 2010:53). Menurut Azwar (2013:5) "Penelitian dengan pendekatan kuantitatif menekankan analisisnya pada data-data numerikal (angka) yang diolah dengan metode stastitik". Desain penelitian menurut Umar (2014:30) merupakan "Semua proses yang diperlukan dalam perencanaan dan pelaksanaan penelitian”. Penelitian ini dilakukan dengan menggunakan Quasi Ekperiment. Arikunto (2010:123) mengatakan "Quasi Ekperiment, yaitu eksperimen yang memiliki perlakuan, pengukuran dampak, unit eksperimen namun tidak menggunakan penugasan acak untuk menciptakan perbandingan dalam rangka menyimpulkan perubahan yang disebabkan perlakuan. Pada penelitian lapangan biasanya menggunakan rancangan eksperiment semu (quasi ekperiment). Penelitian ini difokuskan pada model kooperatif tipe STAD student teams achivement divisions) dalam pembelajaran menulis teks deskripsi pada siswa kelas VII SMP N 12 Tanjung Jabung Timur tahun ajaran 2019/2020. Berdasarkan uraian tersebut penelitian ini menggunakan metode kuantitatif. Dengan demikian pengolahan data hasil penelitian akan dilakukan secara statistik dan hasilnya berupa angka.

\section{Populasi}

Populasi adalah keseluruhan individu yang akan diteliti " Populasi adalah keseluruhan subjek penelitian" (Arikunto,2013:130). Lebih lanjut 
dikemukakan "Populasi secara umum adalah sekumpulan individu dengan ciriciri sama yang hidup dalam tempat dan waktu yang sama" (Syekh, 2011:13). Populasi dalam penelitian ini adalah seluruh Siswa kelas VII SMP Negeri 12 Tanjung Jabung Timur yang berjumlah 90 orang.

Tabel 1.Populasi Kelas VII SMP Negeri 12 Tanjung Jabung Timur

\begin{tabular}{ccc}
\hline No & Kelas & Jumlah Peserta Didik \\
\hline 1 & VII A & 30 \\
\hline 2 & VII B & 30 \\
\hline 3 & VII C & 30 \\
\hline & Jumlah & $\mathbf{9 0}$
\end{tabular}

\section{Sampel}

Menurut Sugiyono (2014:118)

"Sampel adalah bagian dari jumlah dan karakteristik yang dimiliki oleh populasi tersebut. "Sampling atau sampel berarti contoh, yaitu sebagian dari seluruh individu yang menjadi objek penelitian" (Mardalis, 2006:55). Teknik pengambilan sampel dalam penelitian ini adalah random sampling yakni pemilihan subjek secara acak tanpa membedakan strata pada masing-masing kelas. Sampel dalam penelitian ini adalah siswa kelas VII SMP Negeri 12 Tanjung Jabung Timur yang terdiri dari kelas kontrol VII B berjumlah 30 siswa dan kelas eksperimen VII A berjumlah 30 siswa jumlah keseluruhan 60 siswa.

Tabel 2. Sampel Kelas Kontrol VII B SMP Negeri 12 Tanjung Jabung Timur

\begin{tabular}{ccc}
\hline No & Jenis kelamin & Jumlah \\
\hline 1 & Laki-laki & 17 \\
\hline 2 & Perempuan & 13 \\
\hline & Jumlah & $\mathbf{3 0}$
\end{tabular}

Tabel 3. Sampel Kelas Eksperimen VII A SMP Negeri 12 Tanjung Jabung Timur

\begin{tabular}{ccc}
\hline No & Jenis kelamin & Jumlah \\
\hline 1 & Laki-laki & 16 \\
\hline 2 & Perempuan & 14 \\
\hline & Jumlah & $\mathbf{3 0}$
\end{tabular}

\section{Variabel Penelitian}

Variabel penelitian merupakan objek yang akan diteliti. "Variabel merupakan gejala yang bervariasi, yang menjadi objek penelitian" (Arikunto, 2006:126). Dalam penelitian ini terdapat dua variabel, yakni variabel bebas dan variabel terikat.

Variabel bebas disebut juga variabel penyebab (X). Menurut Narbuko (2009:119) "Variabel bebas adalah kondisi-kondisi atau karakteristikkarakteristik yang oleh peneliti dimanipulasi dalam langkah untuk menerangkan hubungannya dengan fenomena yang diobservasi". Variabel bebas dalam penelitian ini adalah model pembelajaran model STAD student teams achivement division.

Variabel terikat disebut juga variabel akibat (Y). Menurut Narbuko (2009:199) "Variabel terikat yaitu kondisi 
atau karakteristik yang berubah atau muncul ketika penelitian mengintroduksi, pengubah atau menganti variabel bebas. Variabel ini (waktu belajar) dimanipulasi atau diubah untuk menyebabkan terjadinya perubahan. Dalam penelitian ini variabel terikatnya adalah keterampilan menulis teks deskripsi.

Teknik pengumpulan data dalam penelitian ini menggunakan teknik tes tertulis. Menurut Riyanto (2011:84) "Tes adalah serentetan atau latihan yang digunakan untuk mengukur keterampilan, pengetahuan, sikap, intelegensi, kemampuan atau bakat yang dimiliki oleh individu atau kelompok".

Penelitian ini harus dilengkapi dengan instrumen penelitian. Wina Sanjaya (2011:84) menyatakan, instrumen penelitian adalah alat yang dapat digunakan untuk mengumpulkan data penelitian, Suharsimi Arikunto (2010: 203) menjelaskan, instrumen penelitian adalah alat yang digunakan oleh peneliti dalam mengumpulkan data agar pekerjaanya lebih mudah dan hasilnya lebih baik, sehingga mudah diolah. Instrumen penelitian yang digunakan dalam penelitian ini berupa tes dan lembar observasi.

Hasil tes, berupa karangan deskripsi siswa kemudian dinilai dengan menggunakan pedoman penilaian menulis karangan deskripsi yang mengadopsi model penilaian yang digunakan pada Program ESL (Englis as a Scound Language) yang dikemukakan Burhan Nurgiyantoro (2010:441-442) dan melihat ciri-ciri karangan deskripsi yang dipaparkan Nursisto (1999:41), dan M. Atar Semi (2007:66-67), serta menyesuaikan dengan materi pembelajaran Bahasa Indonesia SMP kelas VII.

Sesuai dengan metode yang telah dilakukan, prosedur pengolahan data ditempuh melalui sejumlah tahapan, sebagai berikut.

1. Memeriksa karangan siswa berdasarkan aspek yang telah ditentukan.

2. Memberikan skor pada aspek yang diperiksa sesuai dengan ketentuan peskoran yang telah ditetapkan. Kemudian, skor yang diperoleh setiap siswa dihitung sebagai nilai kemampuan siswa yang bersangkutan.

3. Merekap data penelitian yang diperoleh siswa setiap komponen yang diteliti.

4. Menjumlahkan nilai yang diperoleh siswa pada setiap komponen yang diteliti, kemudian mencari nilai rataratanya.

\section{Uji Persyaratan Analisis}

Uji persyaratan analisis yang digunakan dalam penelitian ini adalah uji normalitas dan uji homogenitas. Uji normalitas dan uji homogenitas dapat dijelaskan sebagai berikut.

\section{Uji Normalitas}

Uji normalitas dilakukan untuk mengetahui apakah data yang didapat dari masing-masing variabel berdistribusi normal. Uji normalitas menggunakan rumus chi kuadrat (Chi squer). Adapun prosedur pengujianya adalah sebagai berikut:

1) Menentukan Hipotesis

Ho = data sampel berasal dari populasi berdistribusi normal

$\mathrm{H} 1$ = data sampel berasal dari populasi tidak berdistribusi normal

2) Menentukan rata-rata

3) Menentukan standar deviasi

4) Membuat daftar frekuensi observasi dan frekuensi yang diharapkan

5) Cari $X^{2}{ }_{\text {hitung }}$ dengan rumus: $\mathrm{X}^{2}=\sum\left[\frac{F o-F h}{F h}\right]$

Keterangan:

$\mathrm{X}^{2}=$ nilai Chi-kuadrat yang dicari 
Fo = frekuensi yang ada

$\mathrm{F}_{\mathrm{h}}=$ frekuensi yang diharapkan

6) Cari $X_{\text {tabel }}$ dengan derajat kebebasan $(\mathrm{dk})=$ banyaknya kelas $(\mathrm{k})-1$ dan taraf kepercayaan $95 \%$ atau signifikan $5 \%$

7) Kriteria pengujian

Jika $\mathrm{X}_{\text {hitung }}^{2}<\mathrm{X}_{\text {tabel }} \mathrm{H}_{\mathrm{o}}$ diterima dan $\mathrm{H}_{1}$ ditolak

Jika $\mathrm{X}_{\text {hitung }}^{2}>\mathrm{X}_{\text {tabel }} \mathrm{H}_{1}$ diterima $\mathrm{H}_{\mathrm{o}}$ ditolak

\section{Uji Homogenitas}

Uji homogenitas dimaksudkan untuk menguji terhadap kesamaan (homogenitas) beberapa bagian sampel, yakni seragam tidaknya varian sampel yang diambil dari populasi yang sama. Untuk menguji homogenitas varian tersebut perlu dilakukan uji statistik (test of hemogenity of variances) pada distribusi skor kelompok-kelompok yang bersangkutan. Uji homogenitas dilakukan pada skor hasil pretest dan postest dengan ketentuan jika dinilai signifikansi 0,05 (5\%) maka skor hasil tes tersebut tidak memiliki perbedaan varian atau homogen. Perhitingan homogenitas dilakukan dengan bantuan komputer program SPSS 22.0 .

\section{Uji Hipotesis}

Permasalahan penelitian yang ada dalam rumusan masalah akan dijawab dengan melakukan serangkaian pengujian hipotesis dalam taraf signifikan $\alpha=0,05$. Untuk menganalisis hasil eksperimen yang mengunakan pre-tes post test on groupdesain, maka rumusan yang digunakan adalah sebagai berikut:

$$
\begin{aligned}
& t_{\text {hitung }}=\frac{X 1-X 2}{\sqrt{\frac{(n 1-1) S_{1}^{2}+(n 2-1) S_{2}^{2}}{n 1+n 2-2}}} \\
& \frac{+\left\{\begin{array}{l}
1 \\
1+n 2
\end{array}\right\}}{1}
\end{aligned}
$$

Keterangan:

$\mathrm{X}_{1}=$ mean pos-test

$\mathrm{X}_{2}=$ mean pre-test

$\mathrm{S}_{1}^{2}=$ standar deviasi pos-test

$\mathrm{S}_{2}^{2}=$ standar deviasi pre-test

$\mathrm{n}_{1}=$ jumlah siswa pos-test

$\mathrm{n}_{2}=$ jumlah siswa pre-test (Sugiyono,2014)

Hasil perhitungan data dengan rumus uji-t tersebut kemudian dikonsultasikan dengan dengan $t_{\text {tabel }}$ pada taraf $\alpha=0,05$. Jika $t_{\text {hitung }}$ lebih besar dari

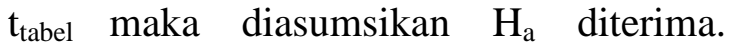
Demikian sebaliknya, jika $t_{\text {hitung }}$ lebih kecil dari $\mathrm{t}_{\text {tabel }}$ maka $\mathrm{H}_{\mathrm{a}}$ ditolak.

\section{HASIL DAN PEMBAHASAN}

Pada bagian ini dikemukakan hasil penelitian pengaruh model kooperatif tipe STAD (student teams achivement division) dalam pembelajaran menulis teks deskripsi kelas VII SMP N 12 Tanjung Jabung Timur. Adapun pembagian hasil penelitian ini adalah deskripsi data hasil penelitian dan analisis data yang akan dijelaskan seperti di bawah ini.

\section{Deskripsi Data Hasil Penelitian}

Penelitian ini dilaksanakan di SMP N 12 Tanjung Jabung Timur tahun ajaran 2019/2020 dan akan dipaparkan seluruh hasil penelitian yang dilakukan pada siswa kelas VII dalam pembelajaran menulis teks deskripsi dengan model kooperatif tipe STAD yang terdiri dari 30 (tiga puluh) orang kelas kontrol dan 30 (tiga puluh) kelas eksperimen. Pada proses pembelajaran, kelas kontrol VII A tidak 
menggunaan model pembelajaran. Kemudian, kelas eksperimen VII B dilakukan proses pembelajaran menggunakan model pembelajaran kooperatif tipe STAD.

Nilai simpangan baku kelas eksperimen lebih kecil dari nilai simpangan baku kelas kontrol artinya rentang nilai tertinggi dan terendah tidak terlalu jauh dengan simpangan baku kelas eksperimen 5.804 sedangkan simpangan baku kelas kontrol 6.573 selanjutnya nilai rata-rata juga menunjukkan pada pembelajaran menulis teks deskripsi menggunakan model kooperatif tipe STAD student teams achivement division dengan kelas eksperimen lebih baik daripada kelas kontrol dengan nilai rata-rata kelas eksperimen sebesar 82.63 sedangkan nilai rata-rata kelas kontrol sebesar 70.20.

Tabel 4. Distribusi Frekuensi Kelas Kontrol Siswa Kelas VII SMP N 12 Tanjung Jabung Timur dalam Pembelajaran Menulis Teks Deskripsi

\begin{tabular}{|c|c|}
\hline Nilai & Presentase (\%) \\
\hline $85-88$ & 0 \\
\hline $81-84$ & 3 \\
\hline $77-80$ & 10 \\
\hline $73-76$ & 27 \\
\hline $69-72$ & 20 \\
\hline $65-68$ & 20 \\
\hline $61-64$ & 10 \\
\hline $57-60$ & 10 \\
\hline Total & 100 \\
\hline $\begin{array}{l}\text { Berdasarkan tabel distribusi } \\
\text { frekuensi di atas diperoleh data pada } \\
\text { pembelajaran menulis teks deskripsi dan } \\
\text { berdasarkan tabel distribusi frekuensi } \\
\text { tersebut siswa yang mendapat niai } 57-60 \\
\text { berjumlah } 3 \text { orang dengan presentase } 10 \% \text {, } \\
\text { yang mendapat nilai } 61-64 \text { berjumlah } 3 \\
\text { orang dengan presentase } 10 \% \text {, yang } \\
\text { mendapat nilai } 65-68 \text { berjumlah } 6 \text { orang } \\
\text { dengan presentase } 20 \% \text {, yang mendapat } \\
\text { nilai } 69-72 \text { berjumlah } 6 \text { orang dengan } \\
\text { presentase } 20 \% \text {, yang mendapat nilai } 73- \\
76 \text { berjumlah } 8 \text { orang dengan presentase } \\
27 \% \text {, yang mendapat nilai } 77-80 \\
\text { berjumlah } 3 \text { orang dengan presentase } 10 \% \text {, } \\
\text { yang mendapat nilai } 81-84 \text { berjumlah } 1\end{array}$ & $\begin{array}{l}\text { orang dengan presentase } 3 \% \text { yang } \\
\text { mendapat } 85-80 \text { berjumlah } 0 \text { orang dengan } \\
\text { presentase } 0 \% \text {.(bisa dilihat pada } \\
\text { lampiran9) } \\
\quad \text { Dari uraian di atas dalam } \\
\text { pembelajaran menulis teks deskripsi kelas } \\
\text { VII SMP N } 12 \text { Tanjung Jabung Timur di } \\
\text { simpulkan bahwa presentase tertingg } \\
\text { kelas kontrol pada nilai } 73-76 \text { berjumlah } 8 \\
\text { orang dengan presentase } 27 \% \text { sedangkan } \\
\text { dengan presentase terendah kelas kontro } \\
\text { pada nilai } 81-84 \text { berjumlah } 1 \text { orang dengan } \\
\text { presentase } 3 \% \text {. Selanjutnya tabel distribusi } \\
\text { frekuensi kelas eksperimen sebagai } \\
\text { berikut. }\end{array}$ \\
\hline \multicolumn{2}{|c|}{$\begin{array}{l}\text { Tabel 5. Distribusi Frekuensi Kelas Eksperimen Siswa Kelas VII SMP N } 12 \text { Tanjung } \\
\text { Jabung Timur dalam Pembelajaran Menulis Teks Deskripsi }\end{array}$} \\
\hline Nilai & Presentase $(\%)$ \\
\hline $95-98$ & 3 \\
\hline 91-94 & 7 \\
\hline $87-90$ & 17 \\
\hline $83-86$ & 30 \\
\hline
\end{tabular}

Pengaruh Penggunaan Model Kooperatif Tipe STAD terhadap Keterampilan Menulis Teks Deskripsi Siswa Kelas VII SMP Negeri 12 Tanjung Jabung Timur 


\begin{tabular}{ccl}
\hline $79-82$ & 4 & \multicolumn{1}{c}{13} \\
\hline $75-78$ & 9 & \multicolumn{1}{c}{30} \\
\hline Total & 30 & \multicolumn{1}{c}{100} \\
\hline Berdasarkan tabel distribusi & $\begin{array}{l}\text { presentase terendah kelas eksperimen pada } \\
\text { nilai 95-98 berjumlah 1 orang dengan }\end{array}$ \\
$\begin{array}{l}\text { frekuensi di atas diperoleh data pada } \\
\text { pembelajran menulis teks deskripsi dengan } \\
\text { menggunakan model kooperatif tipe STAD }\end{array}$ & $\begin{array}{l}\text { presentase 3\% dan 91-94 berjumlah 2 } \\
\text { orang dengan presentase 7\%. }\end{array}$
\end{tabular}
student teams achivement division dan berdasarkan tabel distribusi frekuensi tersebut siswa yang mendapat nilai 75-78 berjumlah 9 orang dengan presentase $30 \%$, yang mendapat nilai $79-82$ berjumlah 4 orang dengan presentase $13 \%$, yang mendapat nilai $83-86$ berjumlah 9 orang dengan presentase $30 \%$, yang mendapat nilai $87-90$ berjumlah 5 orang dengan presentase $17 \%$, yang mendapat nilai $91-$ 94 berjumlah 2 orang dengan presentase 7 $\%$, yang mendapat nilai $95-98$ berjumlah 1 orang dengan presentse 3\%. (bisa dilihat pada lampiran 8)

Dari uraian di atas, diketahui dalam pembelajarn menulis teks deskripsi dengan menggunakan model koopreatif tipe STAD student teams achivment division kelas VII SMP N 12 Tanjung Jabung Timur disimpulkan bahwa presentase tertinggi kelas eksperimen pada nilai 75-78 berjumlah 9 orang dengan presentase $30 \%$ dan $83-86$ berjumlah 9 orang dengan presentase $30 \%$ sedangkan

\section{Analisis Data}

Analisis data bertujuan untuk mengetahui pemecahan masalah terhadap pengaruh model kooperatif tipe STAD (student teams achivement division) dalam pembelajaran menulis teks deskripsi. Data yang dianalisis merupakan data tes pembelajaran menulis teks deskripsi pada kelas kotrol dan kelas eksperimen. Langkah-langkah yang dilakukan dalam penelitian ini melakukan uji normalitas, uji homogenitas, dan uji hipotesis. Adapun analisis data sebagai berikut.

\section{Uji Normalitas}

Uji normalitas dilakukan untuk mengetahui apakah data yang didapat dari masing-masing variabel berdistribusi normal. Dalam penelitian ini uji normalitas dilakukan dengan uji ShapiroWilk dengan bantuan SPSS 20. Uji normalitas analisis data dapat dilihat pada tabel

berikut.

Tabel 6. Uji normalitas Analisis data

\begin{tabular}{|c|c|c|c|c|c|c|c|}
\hline \multirow{2}{*}{\multicolumn{2}{|c|}{ Keterangan }} & \multicolumn{3}{|c|}{ Kolmogorov-Smirnov $^{a}$} & \multicolumn{3}{|c|}{ Shapiro-Wilk } \\
\hline & & Statistic & $d f$ & Sig. & Statistic & df & Sig. \\
\hline \multirow{2}{*}{$\begin{array}{l}\text { Hasil Belajar } \\
\text { Siswa }\end{array}$} & Kelas Kontrol & , 108 & 30 & ,200* & ,984 & 30 & 0,921 \\
\hline & Kelas Eksperimen & , 108 & 30 & ,200* & ,938 & 30 & ,080 \\
\hline
\end{tabular}

Berdasarkan uji normalitas yang dilakukan diperoleh nilai kelas kontrol sebesar 080 dan nilai kelas eksperimen sebesar 0,921 > 0,05 (taraf signifikan). Jadi dapat disimpulkan, dari data kelas kontrol maupun kelas eksperimen berdistribusi normal. (bisa dilihat pada lampiran 13)

\section{Uji Homogenitas}

Tes yang digunakan dalam uji homogenitas adalah uji $\mathrm{F}$ yaitu dengan membandingkan variansi terbesar dan variansi terkecil. Syarat variansi bersifat 
homogen apabila $\mathrm{F}_{\text {hitung }}$ lebih kecil dari pada $\mathrm{F}_{\text {tabel }}$ pada taraf signifikansi $\alpha 0,05$.

Uji homogentitas analisis data dapat dilihat pada tabel berikut.

Tabel 7. Uji Homogenitas Analisis Data

\begin{tabular}{|c|c|c|c|}
\hline \multicolumn{4}{|c|}{ Test of Homogeneity of Variances } \\
\hline \multicolumn{4}{|c|}{ Hasil Belajar Siswa } \\
\hline $\begin{array}{l}\text { Levene } \\
\text { Statistic }\end{array}$ & df1 & df2 & Sig. \\
\hline ,464 & 1 & 58 & 0,498 \\
\hline
\end{tabular}

homogenitas mengunakan program SPSS di peroleh nilai signifikan 0,496 lebih besar dari 0,05 maka dapat disimpulkan bahwa data tersebut adalah homogen.

\section{Pengujian Hipotesis}

Berdasarkan uji normalitas dan uji homogenitas, diperoleh hasil bahwa kelas kontrol dan kelas eksperimen berdistribusi normal dan kedua varians homogen, maka selanjutnya data dapat dilakukan uji hipotesis. Pengujian hipotesis dilakukan untuk mengetahui apakah penggunaan model kooperatif tipe STAD student teams achievement division berpengaruh dalam penulisan pembelajaran menulis teks deskripsi. Dalam penelitian ini uji hipotesis menggunakan uji-t. Uji hipotesis statistik ini adalah $\mathrm{H}_{\mathrm{o}}: \mu_{1}-\mu_{2}$ dan $\mathrm{H}_{\mathrm{a}}: \mu_{1}>$ $\mu_{2}$.

Berdasarkan hasil perhitungan yang telah dilakukan, diketahui bahwa diperoleh $t_{\text {hitung }}$ sebesar 7.766 untuk nilai $\mathrm{t}_{\text {tabel }}$ diperoleh dari tabel $\mathrm{t}$ dengan $\mathrm{dk} 28$ dan taraf signifikan $(\alpha)$ 0,05. Dengan membandingkan nilai $t_{\text {hitung }}$ dengan $t_{\text {tabel }}$ ini bearti $\mathrm{H}_{\mathrm{o}}$ ditolak dan $\mathrm{H}_{\mathrm{a}}$ diterima, jadi dapat disimpulkan bahwa penggunaan model koopertif tipe STAD menjadikan kemampuan menulis teks deskripsi lebih baik.

Berdasarkan hasil analisis data yang dilakukan sebelumnya, maka dalam penelitian ini pada penelitian kelas kontrol siswa tidak diberi perlakukan ataupun model pembelajaran dan siswa juga tidak materi pembelajaran sedangkan pada kelas eksperimen siswa diberi model pembelajaran yaitu model kooperatif tipe STAD. Berdasarkan uji yang telah dilakukan, terlihat bahwa nilai rata-rata pada kelas eksperimen sebesar 82.63 dan pada kelas kontrol 70.20 bearti nilai ratarata siswa yang diajarkan menggunkan model kooperatif tipe STAD student teams achisment division pada kelas eksperimen lebih tinggi daripada nilai rata-rata kelas kontrol. Dalam proses pembelajaran siswa lebih aktif ketika diberi model pembelajaran terutama model kooperatif tipe STAD.

Model pembelajaran kooperatif tipe STAD student teams achivement division membuat siswa lebih aktif dalam pembelajaran, model pembelajaran kooperatif tipe STAD student teams achivement division juga membantu siswa sebagai jembatan untuk menciptakan bentuk atau gambaran melalui pengamatan lingkungan sekolah, perpustakaan, taman sekolah yang akan membuka ide kreatif dalam berkarya khususnya dalam pembelajaran menulis teks deskripsi. Sebaliknya, ketika siswa diberi tugas tanpa diberi perlakuan ataupun menjelaskan materi dan tujuan pembelajaran pada kelas kontrol siswa merasa bingung untuk mengerjakan tugas yang telah diberikan bahkan cenderung pasif hal ini sejalan dengan pendapat Slavins (2005:143)

Proses pemebelajaran yang telah diajarkan pada siswa kelas VII SMP N 12 
Tanjung Jabung Timur dalam pembelajaran menulis teks deskripsi dengan menggunakan model kooperatif tipe STAD ini mempunyai langkahlangkah pembelajaran pada kelas eksperimen yaitu memberikan tujuan dan kompetensi dasar pada pemberian tujuan dan kompetensi dasar ini supaya siswa mengetahui arah dalam pembelajaran sehingga siswa fokus dengan apa yang telah ditentukan. Kemudian, menjelaskan hubungan materi yang telah diajarkan dalam proses ini guru memberi ulasan atau penjabaran singkat tentang kosakata, kaidah penulisan atau ejaan dan hal yang lain berkaitan dengan keterampilan menulis.

Proses pembelajaran selanjutnya pada kelas eksperimen ialah menjelaskan tentang objek yang akan diamati, dalam proses ini guru menjelaskan kegiatan yang siswa jalani dalam proses pembelajaran selanjutnya mulai dari menentukan objek yang akan diamati sampai penilaian dan yang akan dinilai yaitu isi, struktur teks, kosakata, kalimat, kebahasaan, dan ciriciri. Kemudian, guru dan siswa aktif dalam pembelajaran, dalam proses ini guru harus bisa menjadi motivator dan fasilitator yang baik supaya pembelajaran terlaksana dengan baik dan tercapai tujuan pembelajaran. Guru harus mempunyai pengetahuan yang luas tentang objek yang disukai siswa, pada proses ini memudahkan siswa dan membuat siswa tambah aktif.

Pemberian model STAD ini juga memberikan arahan kepada siswa untuk mengamati objek yang akan ditulis, dan memberikan kebebasan agar siswa terarah dalam menulis teks deskripsi dengan menggunakan model kooperatif tipe STAD dan mengevaluasi pembelajaran apakah berhasil atau tidak. Model pembelajran kooperatif tipe STAD sangat membantu siswa dalam mengambarkan khususnya pembelajaran menulis teks deskripsi.

Proses pembelajaran selanjutnya pada kelas kontrol guru tidak menjelaskan tentang aspek penilaian yaitu isi, struktur teks, kosakata, kalimat, kebahasaan, dan ciri-ciri. kemudian, tidak adanya motivator dan fasilitator membuat siswa sulit untuk memulai menulis pada pembelajaran menulis teks deskripsi sehingga individu yang menentukan berhasil atau tidak dalam membuat karangan yang ditulis.

Berdasarkan paparan di atas dalam proses pembelajaran terlihat bahwa penggunakan model kooperatif tipe STAD berpengaruh pada pembelajaran menulis teks deskripsi. Sesuai dengan uji hipotesis yang dilakukan dimana nilai $t_{\text {hitung }}$ lebih besar dari $t_{\text {tabel. }}$ Jadi dapat disimpulkan bahwa kelas eksperimen lebih baik dari kelas kontrol karena pada kelas kontrol tidak diberi perlakuan atau penggunaan model, tidak mengetahui tujuan dan materi pembelajaran sedangkan pada kelas eksperimen diberi model pembelajaran kooperatif tipe STAD dengan memberikan petunjuk lewat objek yang disesuaikan dengan minat siswa, dan siswa lebih memahami dengan yang diajarkan guru.

\section{SIMPULAN}

Berdasarkan hasil penelitan, dapat disimpulkan bahwa penggunaan model pembelajaran kooperatif tipe STAD (student teams achivement division terhadap keterrampilan menulis teks deskripsi siswa kelas VII SMP N 12 Tanjung Jabung Timur tahun pelajaran 2019/2020 diperoleh nilai rata-rata kelas eksperimen sebesar 82.63 dan kelas kontrol memperoleh nilai rata-rata sebesar 70.20 Berdasarkan pengujian hipotesis diperoleh bahwa penggunaan model kooperatif tipe STAD berpengaruh dalam pembelajaran menulis teks deskripsi. Hal 
ini dibuktikan dengan pengujian hipotesis mengunakan uji-t bahwa diperoleh $\mathrm{t}_{\text {hitung }}$ sebesar 7.766 lebih besar dari nilai $t_{\text {tabel }}$ dengan dk 28 diperoleh sebesar 2.048 bearti ini sesuai dengan kriteria pengujian maka $\mathrm{H}_{\mathrm{a}}$ diterima. Dengan demikian model kooperatif tipe STAD dapat digunakan dalam pembelajaran menulis teks deskripsi.

\section{Saran}

Berdasarkan hasil penelitian di atas, maka dapat diberikan beberapa saran sebagai berikut.

1. Hasil penelitian ini dapat digunakan oleh sekolah dalam mengembangkan model pembelajaran yang tepat dan berguna bagi guru untuk mencapai kompetensi pembelajaran yang diharapkan.

2. Hasil penelitian ini dapat digunakan oleh guru dalam menggunakan model pembelajaran khususnya model kooperatif tipe STAD (student teams achivement division) dalam keterampilan menulis teks deskripsi ataupun lainya.

\section{DAFTAR PUSTAKA}

Arikunto, Suharsimi. (2006). Prosedur Penelitian: Suatu Pendekatan Praktik. Jakarta: Rineka Cipta.

Azwar, Syaifudin. (2013). Metode Penelitian. Yogyakarta: Pustaka Belajar.

Keraf, G. (2018). Ekposisi dan Deskripsi. Jakarta: Rineka Cipta

Narbuko, Cholid dan Abu Ahmad. (2009). Metodologi Penelitian. Jakarta: Bumi Aksara.

Riyanto, Yatim. (2011). Metodologi Penelitian Pendidikan. Surabaya: Sic.

Rofii, A., Murtadho, F., Rahmat, A. (2019 C) "The Effectiveness of Contextual-Based Academic
Writing Learning Model. Asian ELF Journal.Volume 23. Issue 6.3 November 2019.

https://www.asian-efljournal.com/main-journals/2019main-journal/volume-23-issue-6-3november-2019/.

Rofii, Afif., Fathiaty, Murtadho., Rahmat, Aceng. (2019 A). Needs Analysis: A Learning Model for CTL-Based Academic Writing. Proceedings of the Eleventh Conference on Applied Linguistics (conaplin 2018) https://www.atlantispress.com/procedings/conaplin18/125911424

Rofii, Afif., Murtadho, Fathiaty., Rahmat, Aceng. (2019 B). The Perception of Lecturers and Students on Learning Model of ContextualBased Academic Writing.

Proceeding First International Conference on Advances in Education, Humanities, and Language. Malang: EAI (https://eudl.eu/doi.418/eai.23-32019.2284915

Rusman. (2010). Model-model Pembelajaran. Jakarta: PT Raja Grapindo Persada.

Slavin, Robert.E. (2005). Cooperative Learning. London. Nusa Media.

Sukmadinata, Nana Syaodih (2010). Metode Penelitian Pendidikan. Bandung: Remaja Rosdakarya Sugiyono. 2014. Metode penelitian Pendidikan Pendekatan Kuantitatif Kualitatif dan $R \& d$. Bandung: Alfabeta.

Syekh, Sayid. (2011). Pengantar Statistik Ekonomi dan Sosial. Jakarta: Gaung Persada.

Tarigan, Henry Guntur. (2013). Menulis Sebagai Suatu Keterampilan Berbahasa. Bandung: Angkasa. 